\title{
5 Action Research and Tourism Studies
}

\author{
Gayle Jennings
}

\begin{abstract}
Action research is a participatory, democratic process concerned with developing practical knowing in the pursuit of worthwhile human purposes, grounded in a participatory worldview ... It seeks to bring together action and reflection, theory and practice, in participation with others, in the pursuit of practical solutions to issues of pressing concern to people, and more generally the flourishing of individual persons and their communities. Reason and Bradbury, 2006a: 1
\end{abstract}

As a process of inquiry, action research is not a recent phenomenon of the 20th and 21 st centuries. Throughout history, humans have engaged in action research processes (Hall, 2001) in order to solve applied issues. More contemporaneously, in the 20th and to some degree in the 21st century, such an applied focus and emphasis on practice within social settings has generated a number of criticisms of action research. Primarily, it is perceived as a process best situated in the realm of consultancy work; having little scientific basis; privileging practical knowing over thinking knowing; having no 'theory'; and being subjectively and intersubjectively determined instead of objectively determined. Most criticisms have predominantly emerged from within hegemonic positivist or postpositivistic stances regarding what constitutes 'research' and relationships between theory and practice. Importantly for action research, it emphasises the practical outcomes of research that arise in the course of cyclical phases of 'planning', 'action' and 'fact-finding' (Lewin, 1946: 38). Its intent is 'the unity of theory and practice' (Anonymous in Dewey, 1938: 7) for social 'good'. While Dewey was referring to education, he like Lewin is associated with influencing the field of action research. As you work through this chapter you will see that these criticisms are well countered with regard to action research, and its approach to both theory and practice. Paradigmatically, all research is informed by a set of principles. From a qualitative perspective, action research is informed by the participatory paradigm as well as social constructivism and critical theory orientation. These paradigms are discussed in more detail later in this chapter.

Action research is attributed as having several origins. A number of people are noted as early contributors to the 'science' of action research; along with the influences of Lewin, a social psychologist, and Dewey, an educational theorist, are John Collier, an American Indian Affairs Commissioner (1933-1945), and Eric Trist, an applied psychologist, as well as others at the Tavistock Institute (Pasmore, 2006). In the 1940s, the term action research was reportedly coined around the same time by Kurt Lewin and John Collier although independently from each other (French \& Bell, 1984). Among action research students, Collier is less well known than Lewin (Pasmore, 2006: 39). Regardless of its origins, action research is a positively focused, outcomes-oriented, 'inquiry-in-action' approach (Reason \& Bradbury, 2006b: xxii). Rather than view action research as a methodology, Bradbury and Reason (2003: xxi) consider it an 'orientation towards inquiry' as well as an ' orientation of inquiry'.

Action research serves to insert 'action' into knowledge creation; to disrupt hegemonies associated with the generation and use of knowledge beyond tertiary education organisations, recognised research centres and bodies; as well as to reshape Western-centric positivistic world views of 'economic progress' value systems (Reason \& Bradbury, 2006b: xxiii). Reason and Bradbury (2006a: 2) argue that the "characteristics of action research ... imply an "action turn" in research practice which builds on and takes us beyond the "language turn" of recent years: the language turn drew our attention to the way knowledge was a social construction; the action turn accepts this, and asks us to consider how we can act in intelligent and informed ways in a socially constructed world'.

So, what is action research? Action research is 'field based, longitudinal and engaged' inquiry that primarily uses qualitative research methods; although, if relevant, quantitative methods may be included (Reason \& Bradbury, 2006b: xxiv). Action research simultaneously integrates theory and practice whereas 'traditional research and its application' primarily remain disconnected processes (Reason \& Bradbury, 2006b: xxiv). Reason and Torbert (2001: 1) refer to this integration as 'research/practice'. The traditional approach has resulted in research or knowledge generation being undertaken by researchers and knowledge applications by practitioners. As Lewin (1939: 35) noted, 'Research that produces nothing but books will not suffice'. In 2001, Reason and Torbert (2001: 1) advanced that given the variety of action-oriented approaches used in social science research, as already noted, a 'turn to action' was occurring. Later, the latter was described by Reason and Bradbury (2006b: xxiii) as a 'turn to reflexive action'.

Finally, to conclude this section, it is important to note that action research is not just a phenomenon of Western-centric thinking; its application and engagement has been global (Fals Borda, 2006 in Reason \& Bradbury, 2006a: 3). For example, participatory research (PR) has been used in development work in Tanzania (Swantz et al., 2006); and participatory action research (PAR) has been used in Latin America (Fals Borda, 2006). Although it may appear that we have been talking about action research as a singular approach, as is evident by the terms used in these two examples, in fact as Reason and Torbert (2001) recognised, there are a variety of action research approaches each with its own key instigators and aligned researchers and these are presented in this chapter (see Tables 5.1 and 5.2). 
Table 5.1 Early classifications of action research and accompanying descriptions

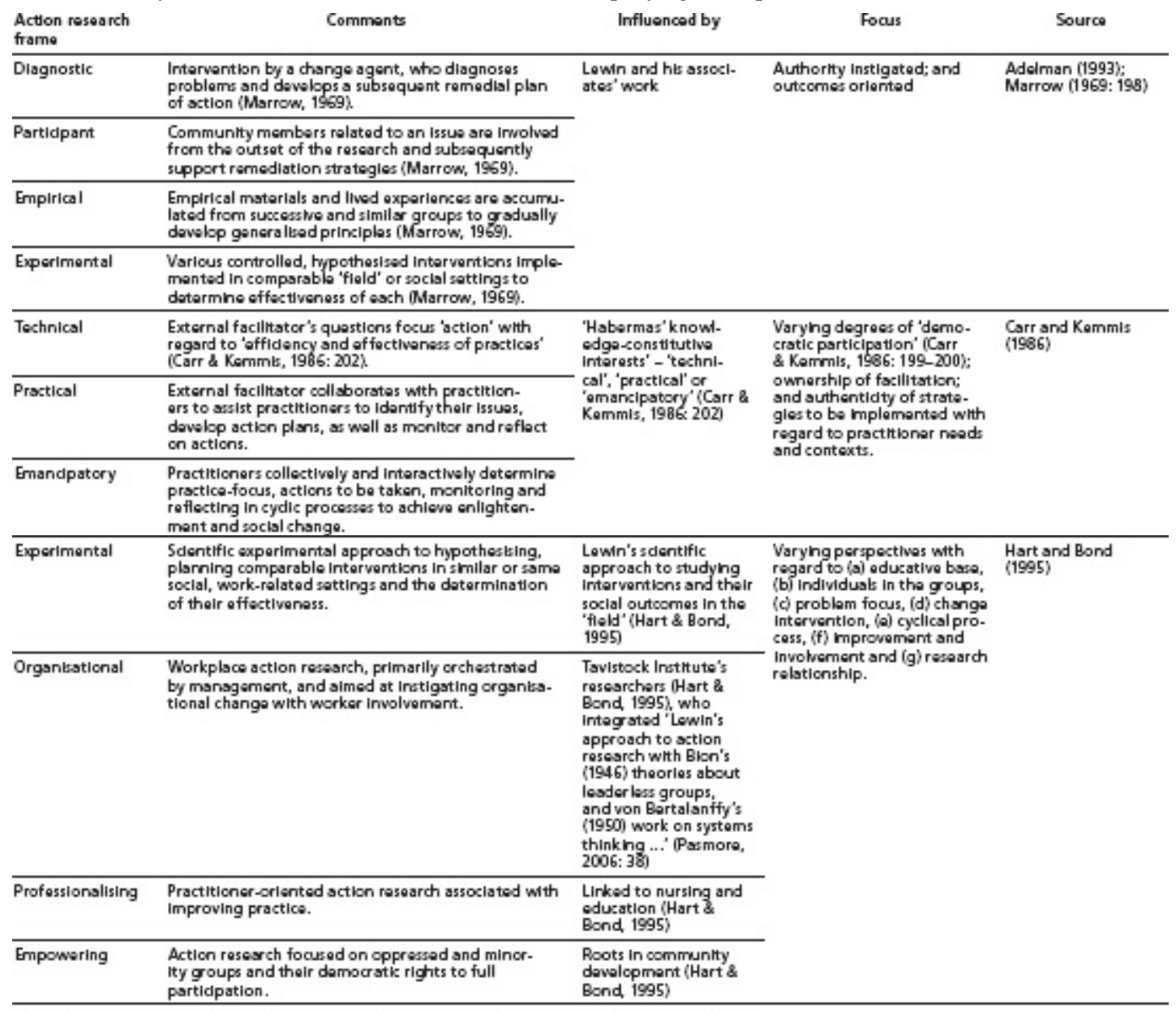

Source: Based on Adelman (1993), Carr and Kemmis (1965), Hart and Bond (1995) and Marrow (1969).

\section{Overview of Action Research and Background to its Common Usage}

the primary purpose of action research is not to produce academic theories based on action; nor is it to produce theories about action; nor is it to produce theoretical or empirical knowledge that can be applied in action: it is to liberate the human body, mind and spirit in the search for a better, freer world. (Reason \& Bradbury, 2006a: 2)

As already intimated, action research aligns with constructivist and critical theory orientation paradigmatic perspectives towards research. Action research also aligns with the participatory paradigm. Compared to the better-known paradigms of positivism, postpositivism, constructivism and critical theories, the participatory paradigm is a more recent development. In 1997, as a result of the extensive use of action research and cooperative inquiry, Heron and Reason advanced the case for a fifth paradigmatic position - a participatory paradigm. They argued that Guba's (1990) and Guba and Lincoln's (1994: 109) four paradigmatic positions, that is, positivism, postpositivism, 'critical theory et al.' and constructivism, were insufficient. At that time, underneath the umbrella term critical theory et al. were clustered, for example, 'neo Marxism, feminism, materialism, and participatory inquiry' (Guba \& Lincoln, 1994: 109). Heron and Reason (1997) purported that a fifth paradigmatic position existed - a participatory paradigm. This fifth paradigm was predicated on knowledge co-creation between researchers and co-researchers/participants in the processes of jointly engaging in experiences and interactions. 'Social practices' and 'collective language' mediate such experiences and interactions (Heron \& Reason, 1997: 278). In response to Heron and Reason's argument, Lincoln and Guba (2000), Guba and Lincoln (2005) and Lincoln et al. (2011) have successively included this fifth paradigm in their discourse and tabular representations of theoretical paradigms that inform research processes. In the following five paragraphs, we look further at the participatory paradigm as well as consider it in relation to social constructivism and critical theories paradigms. In those paragraphs, I have incorporated the various authors' language and vocabulary to describe the three paradigms in order to maintain the specificity of their discourses.

Table 5.2 Contemporary types and practices of action research, definitions and related researchers 


\begin{tabular}{|c|c|c|}
\hline Type of axtion rese areh & Deflinkbon & Palated restesrechen \\
\hline Actisn rasanch & 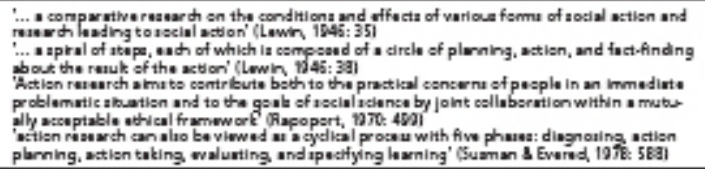 & 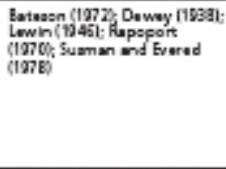 \\
\hline $\begin{array}{l}\text { Cooperatwe fecological } \\
\text { mopiry }\end{array}$ & 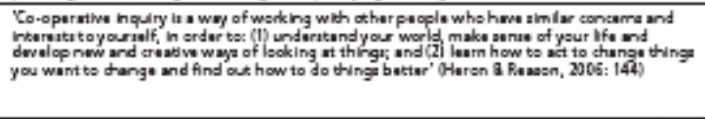 & 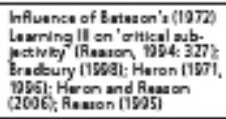 \\
\hline $\begin{array}{l}\text { Developmantal ation } \\
\text { mquiryitatearch }\end{array}$ & 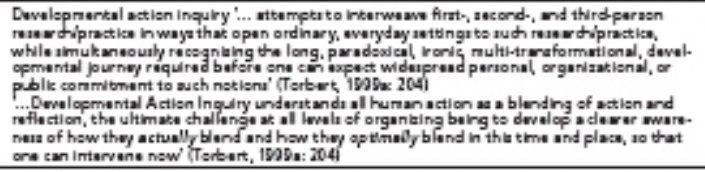 & Terbert (15BDa) \\
\hline Actisn scienca & 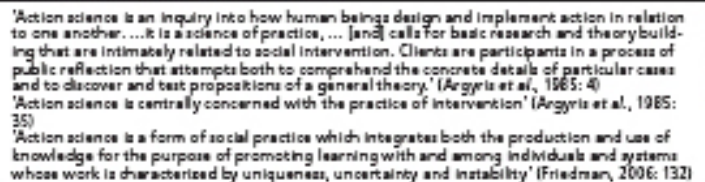 & 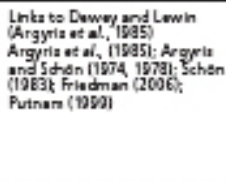 \\
\hline कताइत hquाry & 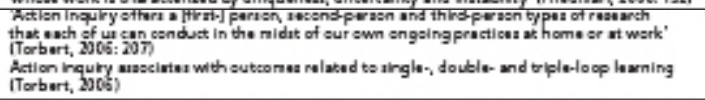 & 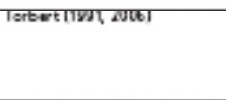 \\
\hline \multirow[t]{2}{*}{ 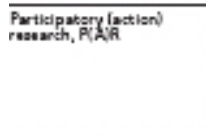 } & \multirow{2}{*}{ 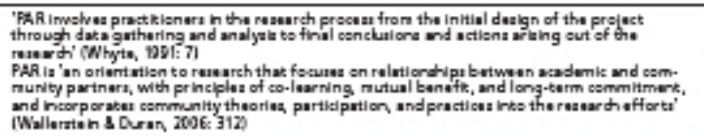 } & Linka to Paulo Frere (1976) \\
\hline & & 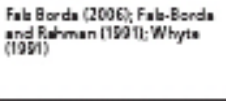 \\
\hline $\begin{array}{l}\text { Same forms of fominist } \\
\text { nquiry }\end{array}$ & 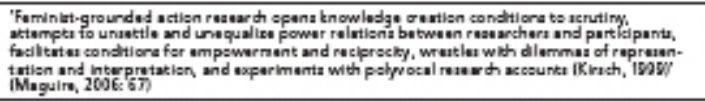 & 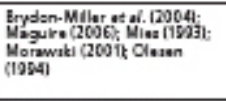 \\
\hline $\begin{array}{l}\text { Enancleat ory action } \\
\text { rasuanch }\end{array}$ & 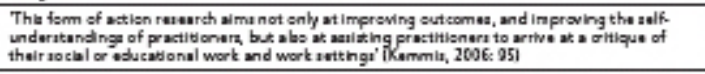 & $\begin{array}{l}\text { Carr and Kammia (19E5): } \\
\text { Karmmia L2005) }\end{array}$ \\
\hline Apprescintive inquiry & 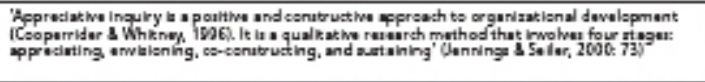 & 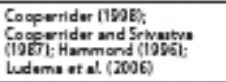 \\
\hline $\begin{array}{l}\text { Fourth-genaratisen } \\
\text { waluntion }\end{array}$ & 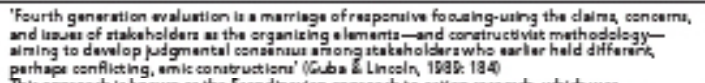 & Guka and Uncein [DEท] \\
\hline $\begin{array}{l}\text { Aetlisn reseanch at demo- } \\
\text { erritic dislogua }\end{array}$ & 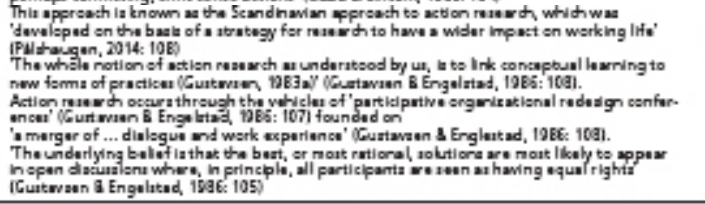 & 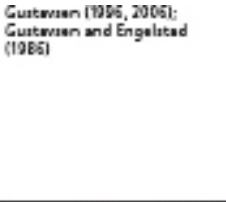 \\
\hline $\begin{array}{l}\text { Communtiky action } \\
\text { rasaanch }\end{array}$ & 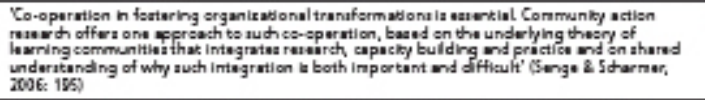 & Senge and Scharmar [2005] \\
\hline Clasurson setion researdh & 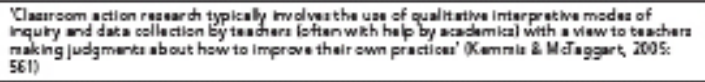 & 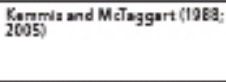 \\
\hline Actisn learning & 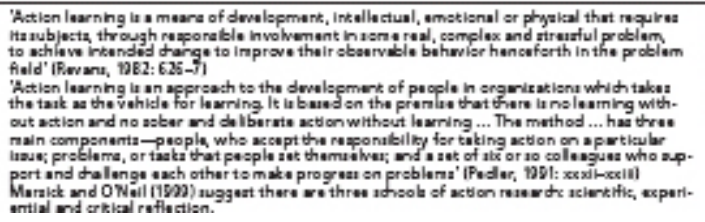 & 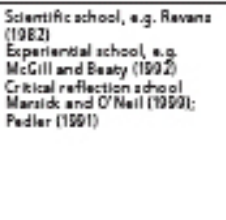 \\
\hline
\end{tabular}

The participatory paradigm is associated with an ontological perspective that is described as 'participative reality' (Lincoln et al., 2011: 100) in which reality is subjectively-objectively known and 'intersubjectively shaped' with others (Heron \& Reason, 1997: 279). Specifically, 'any subjective-objective reality articulated by any one person is done so within an intersubjective field, a context of both linguistic-cultural and experiential shared meanings' (Heron \& Reason, 1997: 280).

Epistemologically, the participatory paradigm recognises that there are four ways of knowing: experientially through 'direct encounter' (Heron \& Reason, 1997: 280) from which arises 'presentational knowing' associated with a variety of art forms to metaphorically symbolise our knowing (Heron \& Reason, 1997: 281); 'propositional knowing' that is, conceptual knowing; and practical knowing, which is, 'how to do something' (Heron \& Reason, 1997: 281). The various ways of knowing interact and the researcher uses 'critical subjectivity' to 'articulate a reality that is unclouded by a restrictive and ill-disciplined subjectivity' (Heron \& Reason, 1997: 280). Given action research's focus on 'knowledge generation and knowledge application' (Reason \& Bradbury, 2006a: xxv), a blurring of boundaries occurs between a traditional, etic-assigned epistemological positioning between a 'researcher and the known (or knowable)' (Guba, 1990: 18).

Methodologically, a participatory paradigm involves a cyclic process that uses collaborative inquiry linking 'critical subjectivity' with 'critical intersubjectivity' and 'democratic dialogue' (Heron \& Reason, 1997: 283). Research questions and methodology are collectively determined using 'propositional knowledge'. The methodology is practically applied in co-researchers/participants' practice worlds drawing on 'practical knowing', which in turn creates new encounters that 
generate 'experiential knowing', which are then collectively identified as 'patterns' and subsequently represented using 'presentational knowing'. Co-researchers/participants collectively cycle through this process 'to enrich ... congruence' (Heron \& Reason, 1997: 283). Essentially, '[t]he research is done by people with each other, not by researchers on other people or about them' (Heron \& Reason, 1997: 284).

Axiologically, the 'primary purpose of human inquiry is practical: our inquiry is our action in the service of human flourishing ... participatory research is thus essentially transformative' (Heron \& Reason, 1997: 288). Relatedly, so is the intention of a critical theories paradigm, albeit that Heron and Reason (1997: 228) argue that 'neither critical theory nor constructivism acknowledge practical knowing, whereas the participatory paradigm regards it as primary'. Additionally, epistemologically 'neither constructivism nor critical theory paradigms recognize the intrinsic value of practical knowing' (Heron \& Reason, 1997: 288); instead they emphasise 'propositional knowing and its instrumental value in generating social emancipation' (Heron \& Reason, 1997: 291). Within the participatory paradigm, epistemologically, practical knowing has primacy, and axiologically, it is of intrinsic value in the participative paradigm (Heron \& Reason, 1997).

We have just explored some comparisons between the participatory paradigm and social constructivism and critical theories paradigms. Given that Guba and Lincoln (1994) had earlier clustered the participatory paradigm under 'critical theory et al.', how does a participatory paradigm distinguish itself from a critical theories paradigm? It does so in the following ways: ontologically, a recognition of 'participative reality' rather than 'historical realism'; epistemologically, an emphasis on 'critical subjectivity' and 'experiential, propositional, practical knowing, co-created findings' instead of 'transactional/subjectivist, value-mediated findings'; methodologically, a focus on 'collaborative action inquiry, primacy of the practical' and shared experientially based language in contrast to 'dialogic/dialectical' approaches (Lincoln et al., 2011: 100); axiologically, embracing 'practical knowing ... [as] an end in itself, ... [and] intrinsically valuable' (Heron \& Reason, 1997: 287) associated with 'human flourishing' (Heron \& Reason, 1997: 287) and transformation compared to instigating change and improving circumstances, which can also be emancipatory and transformative in nature.

That being said, if participants are not co-researchers/co-subjects, then action research may be better framed within a constructivist or a critical theory orientation, the determinant of which is the degree of collaboration that occurs within the research process - complete (participatory) or, for example, mediated as in achieving informed consent of a research plan and making modifications based on participant feedback (constructivist and critical theory).

Having considered the differences between participatory, social constructivism and critical theories paradigmatic views, among extant qualitative action research inquiries there are representations of action research being informed by each of these paradigms as well as a merging of social constructivism and critical theories paradigms 'sometimes to the point of being inseparable' (Reason \& Bradbury, 2006b: xxiv). Also within the literature, there are examples of action research that are more in line with pragmatism, and these tend to relate to more experimentally shaped action research inquiries. However, from a social constructivist, critical theories orientation and especially participatory perspectives, these may be questioned as the key to 'action research is research with, rather than on practitioners' (Reason \& Bradbury, 2006b: xxv) and peoples. Often, as already stated, the latter two groups are co-researchers and are constantly involved in overall research processes and decision-making. In the course of the iterative phases of action research, practice and theory are generatively integrated to improve, change and/or develop circumstances for the better. There is no separation between the production of research outcomes and theory-building - they occur simultaneously.

As researchers, it is important for you to understand the different paradigms that may be associated with action research in order to effectively argue your choice of paradigm. Bear in mind that during your literature searches of the extant literature, you will come across various examples of action research. It is important for you to be able to distinguish which are action research inquiries and which allege to be or only masquerade as action research inquiries. Knowing the related paradigmatic tenets will assist you in this process as well as the tenets of action research. Having said this, the latter is not such an easy task, for while there are overarching tenets, as already noted, there is a multiplicity of action research types. In the following pages, we look at several early classifications of action research as well as a range of more contemporary types of action research. Of course, we do not address every classification or typology or type of action research but sufficient are presented to give you not only an idea of how action research has developed over time but also an insight into some of the key researchers and influencers of the various types. This information is presented in Tables 5.1 and 5.2 and provides a ready-reference from which you can further explore a range of different types of action research and their potential relevance to circumstances that you may be invited, requested, directed or are co-considering with colleagues or community members regarding the use of action research to simultaneously link theory and practice as a means to make positive changes and/or improvements.

The types presented in Table 5.1 are earlier classifications of action research. Although I have classified these as earlier types, currently, they are still variously used. The types have some similarity in categorisation as well as research intent. What differs within classifications is the degree of democratic discussion and decision-making between the research instigator/facilitator/researcher and the participants or co-researchers, the way the issue is identified and the degree of ownership of the outcomes associated with the participants, as well as the focus of the research and orientation of research outcomes.

As you can see from Table 5.1, there are a number of types of action research, or as Reason and Bradbury (2006b: xxii) describe it, a 'family of approaches'. Some further and more contemporary types of action research include: action research 
(Kemmis \& McTaggart, 1988); PAR (Fals-Borda, 2006; Whyte, 1991); PR; appreciative inquiry (Ludema et al., 2006); cooperative inquiry (Heron \& Reason, 2006); communities of inquiry in communities of practice (Friedman, 2006); systems thinking and action research (Flood, 2006); and critical action research (Carr \& Kemmis, 1986; Zuber-Skerritt, 1996). Additionally, different perspectives have informed action research, such as feminism and power and politics, Marxism and change.

Table 5.2 overviews a number of contemporary types of action research. The table provides a definition or several definitions relating to each type, which helps to capture the 'extended epistemologies' (Reason \& Bradbury, 2006a: 9) of each, and identifies researchers and influencers associated with each type. The types presented in Table 5.2 are drawn from Heron and Reason's (1997: 284) listing along with that of Kemmis and McTaggart (2005: 560-562), and representations in Reason and Bradbury (2006). It is not an exhaustive representation.

Finally, a third typology is presented. The three categories of action research presented here were defined by Torbert (1998, 1999a, 1999b) and Reason and Torbert (2001). This typology discusses first-, second- and third-person action research. Each is now described in turn.

(1) 'First person research/practice' (Reason \& Torbert, 2001: 1) engages researchers in inquiring into their own social, cultural and professional worlds to instigate change. This category is also related to the 'reflective practitioner' (Reason, 2004: 281), for example, an individual teacher undertaking change to classroom practice and praxis in isolation from other practitioners. This type of action research is founded on 'subjective research' (Reason \& Torbert, 2001: 2); there is an obvious missing element - a reflective partner or group with whom to engage in reflection. And here caution is required, for as Habermas (1974: 29) commented 'in the act of self-reflection the subject can deceive itself'. However, Reason and Torbert (2001: 17) comment that a person using 'critical subjectivity' akin to Bateson's (1972) Learning III as well as what Torbert (2006: 208) refers to as 'triple-loop learning' should be able to counter this.

(2) 'Second person research/practice' (Reason \& Torbert, 2001: 1) requires the researcher co-researching with others regarding shared concerns to benefit practice, conditions or circumstances. It emphasises 'interpersonal dialogue' and associates with 'communities of inquiry' and 'learning organizations'. It is undertaken, for example, in organisations, businesses, local-level communities, groups, associations and service industry sectors.

(3) 'Third person research/practice' (Reason \& Torbert, 2001: 1) involves large-scale projects drawing on 'communities of inquiry' to engage in networked communication to facilitate transformational changes in communities, organisations and nations. Given the scale of these projects, the changes tend to be associated with broader scale social, cultural, educational, professional and/or political outcomes.

As can be seen from the last typology, and variously in Tables 5.1 and 5.2, action research can involve one person bringing about a positive change in his/her practice; a group of people coming together to generate positive change within organisations and communities as well as large-scale networked communities of inquiry focused on social, cultural and political agendas.

Finally, to conclude this section, '[a]ction research should (among other things) be context related and collaborative, change practice and generate theory' (Lyon, 1998/9: 41). Further, given the various types of action research, and the subsequent choices available, 'there can never be one "right way" of doing action research' (Reason \& Bradbury, 2006b: xxiii) and arguing that one is better than another is a futile activity. Embrace the diversity and determine which approach will enable you and/or others to respond to the issues requiring attention in your professional practice, organisation(s), communities and/or networks. As in any research, the important thing when sharing your inquiry is that you make clear to your audiences the reasons for your choices and substantiate them.

\section{Engaging in Action Research}

Action research is a cyclical process of planning, acting and observing, reflecting; planning, acting and observing, reflecting; planning, ... (Kemmis \& McTaggart, 2005)

Most types of action research are associated with a problem-solving approach (Burns, 2000; Kemmis \& McTaggart, 1988; Whyte, 1989) - changing something for the better. This problem-solving intention has also been defined as a deficit-based model (Cooperrider \& Srivastva, 1987). Cooperrider and Srivastva promote an alternative to this model -appreciative inquiry (see Table 5.2) - which they view as operating from a non-deficit model. In response to such critique, Dick $(2004,2006)$ countered that positive approaches were evident in alternate action research approaches, although this tended to be ignored by appreciative inquiry researchers in their critiques.

Appreciative inquiry was developed by Cooperrider (1986). He was influenced by 'Lewin's (1959) and Gergen's (1985) research on human perceptions and social constructionism, and Vickers' (1980) notion of "appreciative systems" (Koster \& Lemelin, 2009: 258). Essentially, appreciative inquiry involves five principles: the constructivist principle, the principle of simultaneity, the poetic principle, the anticipatory principle and the positive principle. From these principles, assumptions are 
generated that guide appreciative inquiry. Appreciative inquiry as a process involves four stages, also known as the 4D cycle: discovery, dreaming, designing and delivery. Alternately and similarly, the 4I cycle can be used to guide inquiry: initiate, inquire, imagine and innovate.

Just as appreciative inquiry critiques other action research approaches for their deficit-based model, appreciative inquiry has also been critiqued for its non-deficit or positive approach to issues. The first criticism is obvious; appreciative inquiry ignores negative aspects of issues. Other critiques relate to appreciative inquiry's focus on outcomes rather than processes (Grant \& Humphries, 2006: 404-405). And as Bushe (2007) argued, appreciative inquiry focuses more on axiological rather than epistemological and ontological concerns. Despite action research having been described as a deficit model that focuses on a problem-solving approach, Kemmis and McTaggart (1988) note:

It is not simply problem-solving. Action research involves problem-posing, not just problem-solving. It does not start from a view of 'problems' as pathologies. It is motivated by a quest to improve and understand the world by changing it and learning how to improve it from the effects of the changes made. (Kemmis \& McTaggart, 1988: 21)

Having considered both a deficit and a non-deficit approach to action research, as well as outlining the basic stages of appreciative inquiry, the remainder of this section focuses on action research as an approach that applies both problem posing and problem solving to issues.

Taking into account the preceding text and Tables 5.1 and 5.2, if you are thinking about using action research consider the following questions:

(1) What is the issue?

(2) Who recognised that the issue needs to be addressed - a person in authority, management, colleagues, people or groups directly/indirectly connected to/involved in the issue, such as community members, disenfranchised groups, work groups, people directly involved in the outcomes ...? And why?

(3) Who will/has instigate/d addressing the issue - a person in authority, management, colleagues, people or groups involved with the issue, such as community members, disenfranchised groups, work groups, people directly involved in the outcomes ...? And why?

(4) Who will determine how the issue needs to be addressed - a person in authority, management, colleagues, people or groups involved with the issue, such as community members, disenfranchised groups, work groups, people directly involved in the outcomes ...? And why?

(5) Who have/has the most vested interest/s in addressing the issue - a person in authority, management, colleagues, people or groups involved with the issue, people directly involved in the outcomes ...? And why?

(6) Who will drive the action research process - researcher, external facilitator, internal facilitator(s), collectives, communities of inquiries ...? And why?

(7) How democratic will participation in the action research inquiry be? And why?

(8) How will the issue be identified and described - using theory, authoritative perspective, practical knowing, negotiated, collectively and democratically determined ...? And why?

(9) How democratic will the iterative action research processes be regarding planning, decision-making, action-taking, observing, reflecting, planning ...? And why?

(10) What roles will people play - facilitator(s), co-facilitators, researcher(s), co-researchers, participants, 'subjects' ...? And why?

(11) How will theory and practice be co-utilised - will one be more dominant than the other? And why?

(12) What roles will critical subjectivity, critical intersubjectivity, democratic dialogue, reflexive thinking and so on have in the inquiry? And why?

(13) Will the action research inquiry change the status quo, will it change practice and praxis, will it be transformational, will it be emancipatory ...? And why?

(14) How will the 'action' be determined as generating improvement - formal evaluation, by an authority figure, democratically, collectively, consensus, recognition of multiple perspectives and so on?

(15) When will the 'action' be determined as generating improvement - in the process of undertaking action, while fine-tuning/adjusting/changing that action, at a specific point in time, at multiple points in time and so on? And why?

(16) How will theory and practice be linked? And why?

(17) How will 'knowing-in-action' be capitalised upon?

Once you have answers to these questions, you will be able to identify:

(1) if action research is the appropriate research to use;

(2) which paradigm best aligns to inform the integrity of the action research inquiry; and

(3) the nature and type of action research in which you most probably will be engaging.

Refer to the beginning of this chapter to make sure you familiarise yourself with the tenets of the relevant informing paradigm to assist you (and your co-researchers) with planning an action research inquiry. Refer also to Tables 5.1 and 5.2 
and explore some of the literature related to each action research type or approach.

\section{Cyclic Processes of Action Research}

In the following paragraphs, based on Kemmis and McTaggart's (1988; 2005) action research spiral, a simplified representation of action research using iterative processes of planning, acting and observing, as well as reflecting will be applied. This spiral is presented in Figure 5.1. However, when considering the spiral, as Kemmis and McTaggart (2005) noted, it is difficult to figuratively represent social processes. And action research is a social process since it involves social beings. Subsequently, the identified processes are not particularly lockstep in progression, there may be overlap. For example, plans for action may be adjusted during the processes of 'acting and observing'; 'reflecting' may be constantly part of planning, acting and observing. So be aware that the iterative cycles of action research processes may not be as clear-cut as represented in Figure 5.1. That being said, each of the processes associated with the cyclic nature of action research will be considered in their own right.

(1)Issue identification

Usually before engaging in action research, people identify and/or situational contexts indicate that an issue requires redress. This may generate dialogue between affected persons and/or peoples. Such dialogue can lead to discussions with others concerning possible ways forward. The affected group(s), an external action researcher or an action research facilitator will instigate/lead the action research processes. Importantly, and to reiterate, in action research, there needs to be collaboration with those who are affected along with democratic dialogue.

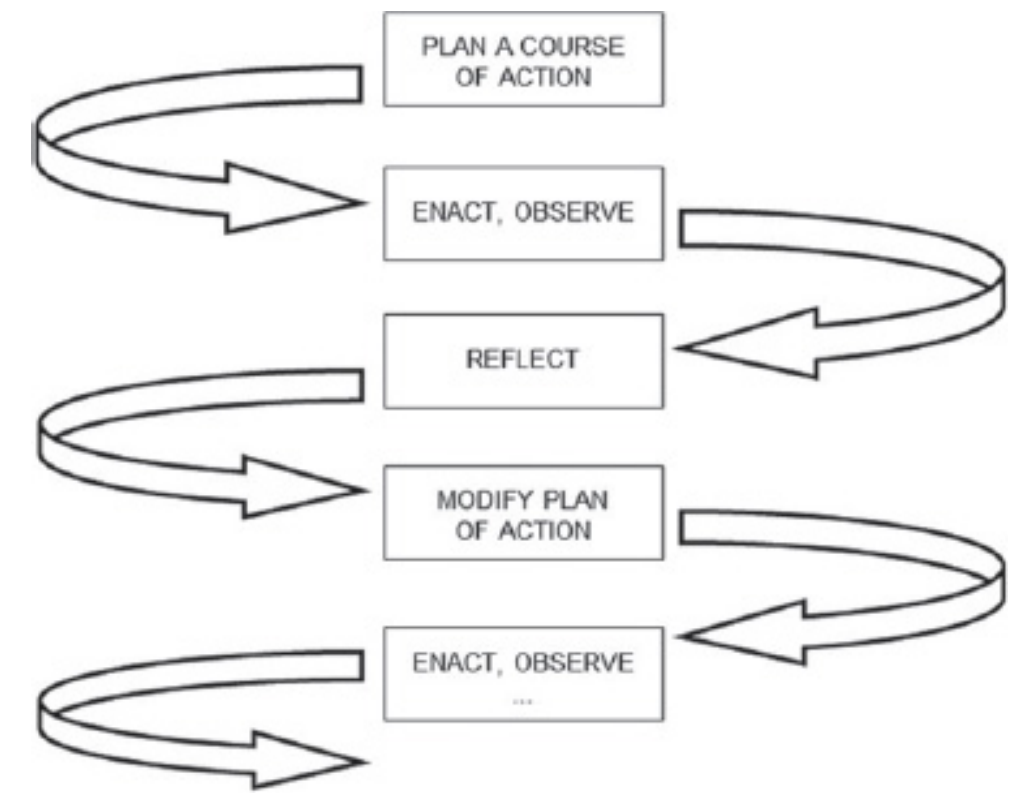

Figure 5.1 Iterative cycles of action research processes (Source: Based on Kemmis and McTaggart, 1988: 11; 2005: 564)

First, the issue has to be identified. The issue, focus or 'subject matter' will generally associate with practices, praxis, processes or 'attitudes, values ... behaviour' (Kemmis \& McTaggart, 1988: 92) or culture. Tourism-specific examples of issues include how to 'improve practices and develop new knowledge' (Bjork, 2014: 184); 'empower... local communities in decision-making' with regard to tourism planning as well as 'tak[e]... research out of ... researchers' academic realms and “ivory tower" analytical procedures' (Paül et al., 2015: 11); 'develop... organisational capabilities' (Kelliher et al., 2009: 80); 'develop... tourism products and ... partnerships' (Schmitz \& Tsobgou, 2016: 143); or 'create change for sustainability in the learning and teaching focus of ... business schools and in the operations of the business schools and their partner corporations' (Thomas \& Benn, 2009: 18). Then, participants will collaboratively and democratically develop a course of action. Prior to doing that, some ground rules should be established regarding participation and behaviour in order to facilitate respectful, democratic and collaborative interactions. If single-person action research is being undertaken, the individual critically self-reflects upon suitable courses of action.

(2)Plan a course of action

In planning a course of action, primarily three things are considered: Who are the participants? What is the focus? and What is the context? During planning phases, participants reflect on who is involved and the degree that they will be co-researchers in the process. Participation may be full and equal if using a participatory paradigm or it may be participation by varying degrees if informed by social constructivism and/or critical theories paradigms. Through reflection and democratic dialogue or reflection and discussion, researchers and co-researchers or researcher and participants will determine and fine-tune the focus or 'subject matter' (Kemmis \& McTaggart, 1988: 92). The context or the setting will be taken into account with regard to spatial (e.g. department, organisation, destination, local, state, national and international), temporal 
(e.g. current times, past and future times), sociocultural (e.g. mores, values, cultures and expectations), economic (e.g. costs and prices, condition of the economy, organisational financial standing) and political (e.g. government policies, regulations, strategies, initiatives) circumstances. Participants may undertake 'research' to assist them in developing a course of action to respond to the issue and improve circumstances. The plan will take into account strategies for change and the roles that people will assume, how reflections and observations will be captured as well as how regularly, and how long the plan will be enacted before a formal group reflection is conducted.

(3)Enact and observe

Variously, researchers and co-researchers, researchers and participants will enact the plan and continuously reflect and monitor its enactment. During the enactment process, observations will be made and captured using a variety of methods, such as journal or diary keeping, gathering of empirical materials from the action research setting, field notes, interviews, focus groups, checklists, questionnaires, multimedia methods or formal methods of evaluation.

(4)Reflect

As already noted in the process of action research, reflection will generally be a constant. Usually, a plan proposes a specific time interval for formal reflection; however, if researchers and co-researchers or participants sense that the plan is not working, it would be irresponsible to continue to enact it; the plan needs to be changed earlier rather than later. That being said, it is important that scheduled reflection times formally evaluate the plan, drawing on the observation materials, the enacted plan materials and co-researcher/participant experiences as well as through democratic dialogue with those affected by the plan.

(5)Modify plan of action

From reflective processes, knowing-in-action/learnings regarding theory/practice are developed and a new plan is developed along with methods for enacting and observing, and reflecting. And this process iteratively continues to sustain learning and improve situational circumstances.

Regardless of whether you are undertaking first-, second- or third-person action research, at their core, these basic processes will inform your research/practice. That being said, it should be noted that this is one of a number of process models involved in action research. Each of the types presented in Tables 5.1 and 5.2 have their own terminology and 'process steps'.

\section{Research Contexts}

The participatory paradigm is especially effective with regard to any research, which is related to facilitating change, engendering collective ownership of and commitment to plans, processes, strategies, and evaluation practices and their practical, in and of the world, applications. (Jennings, 2010: 50)

Within tourism studies, action research has been advocated for instigating change in organisations, to facilitate community development (Jennings, 2010) and local tourism planning processes (Paül et al., 2015). It has also been advocated as a vehicle to facilitate change in curricula and classroom practice and praxis (Jennings et al., 2009). Additionally, Jennings and Seiler (2000) advocated the use of appreciative inquiry as an alternative participatory method to action research for managing change in the tourism industry. A number of researchers have reported using action research for the following purposes: tourism service innovation (Björk, 2014); 'community participation in sustainable rural tourism experience creation' (Idziak et al., 2015: 1341); community participation and empowerment in sustainable tourism development processes (Cole, 2006); 'value chain analysis' (Mitchell, 2012: 457); enhancing a tourism learning network programme (Kelliher et al., 2009: 92) and 'sustaining local language relationships through indigenous community-based tourism initiatives' (Whitney-Squire, 2016: 1156).

Within the hospitality sector, Afify (2008) noted that although the first hospitality-based action research study occurred in the 1940s, few other studies had been conducted until the 21st century. Despite its limited use (Afify, 2008; Lashley, 2000; Waser \& Johns, 2003), Afify (2008: 158) argues its 'potential benefits and relevance to the [hospitality] industry', especially with regard to operations management. Waser and Johns (2003) advocated for the use of action research in the hospitality sector for organisational and professional development. These two researchers advanced that action research would be particularly useful in facilitating cultural change in hospitality organisations. Similarly, Lashley (2000: 314) noted that 'action research can make a significant contribution to lifting both the professionalism of hospitality management and the effectiveness of hospitality management practice' as well as a means to improve educational practice in 'hospitality management education' (Lashley, 2000: 313).

Table 5.3 provides an overview of five action research inquiries drawn from tourism studies and hospitality management. Two tourism and two hospitality examples and one tourism and hospitality education example are presented. For each of the five inquiries, the researchers and the related research paper's title are acknowledged, then the inquiry's focus, intent, approach, informing paradigm and type of action research approach or practice are identified, participants are reported and research methods noted. Readers are referred to the published papers for more information and examples of action research papers.

When conducting a literature search using the term 'action research' to prepare Table 5.3, a number of articles were identified. On searching each of these, several mentioned the word 'action research' in the abstract; others mentioned the 
word 'action research' in the introduction and nowhere else. A few mentioned that action research had been used but it was not identified or explained. Several articles provided background or advocated for the use of action research or a particular type of action research, such as appreciative inquiry, or PAR. Several said they were doing PAR but did not. A limited number of articles explained in detail the nature of the action research that was used, whether it was participatory or constructivist or critical theory informed. In other articles, it was left to the reader to determine. Several papers appeared not to understand action research processes and several others appeared to be using action research in a way that was contrary to its core principles in that it was research 'on' rather than 'with' people. And several others reported that although they had used action research, they had varied methods contrary to the core principles of action research albeit they still referred to their research as action research. Again, action research associates with specific ontological, epistemological, methodological and axiological principles, if a 'researcher' is not following the guidelines of these paradigmatic aspects or the primary tenets of action research then the research does not qualify as action research.

As noted before, when you conduct your own literature search on action research, be a critical reader and evaluate the published exemplars with regard to their commensurability with action research. It is not uncommon for researchers to present and have published work that does not fit the tenets of action research (Carr \& Kemmis, 1986).

So, how do we judge action research, as Marshall and Reason (1994) suggest:

All good research is for me, for us, and for them: it speaks to three audiences. ...It is for them to the extent that it produces some kind of generalizable ideas and outcomes... It is for us to the extent that it responds to concerns for our praxis, is relevant and timely ... [for] those who are struggling with problems in their field of action. It is for me to the extent that the process and outcomes respond directly to the individual researcher's being-in-the-world. (Marshall \& Reason, 1994: 112-113)

\section{Determining Quality in Action Research}

In addition to judging 'good' research, Bradbury and Reason (2006) suggest the following measures for determining the quality of action research inquiries.

(1) Does the inquiry utilise 'relational praxis' (Bradbury \& Reason, 2006: 346)? How cooperative is the inquiry? Are 'participation and authority' (Bradbury \& Reason, 2006: 346) distributed? Is decision-making inclusive? Were those affected by the inquiry issue and processes assisted by their participation in the inquiry?

Table 5.3 Examples of action research in tourism studies and hospitality management

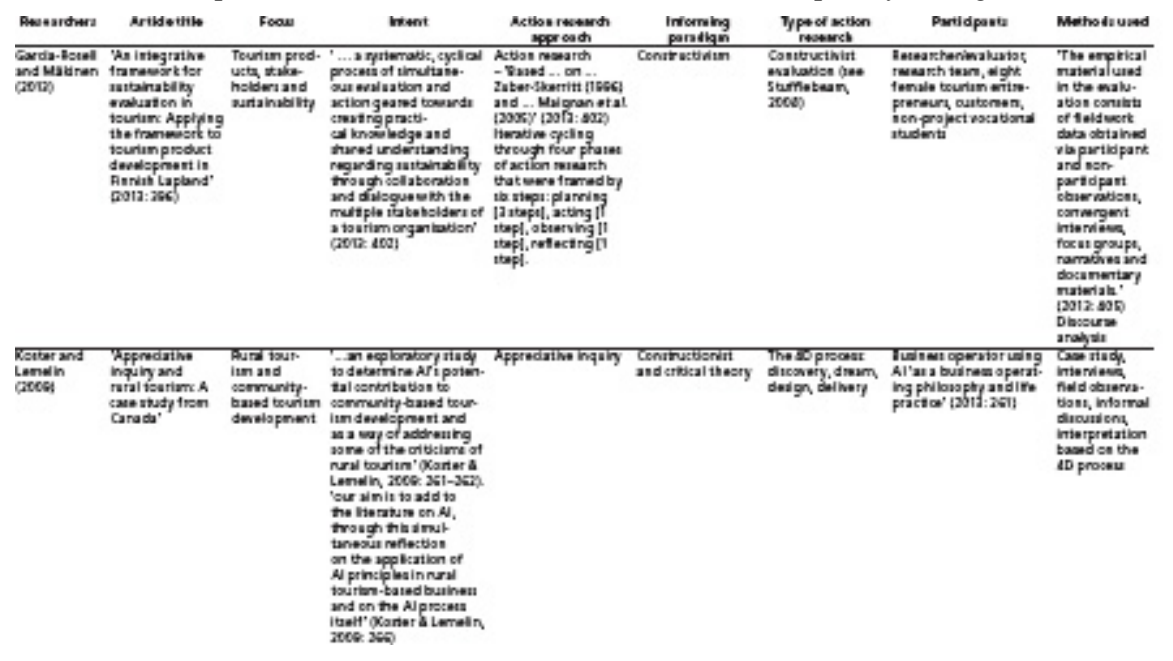




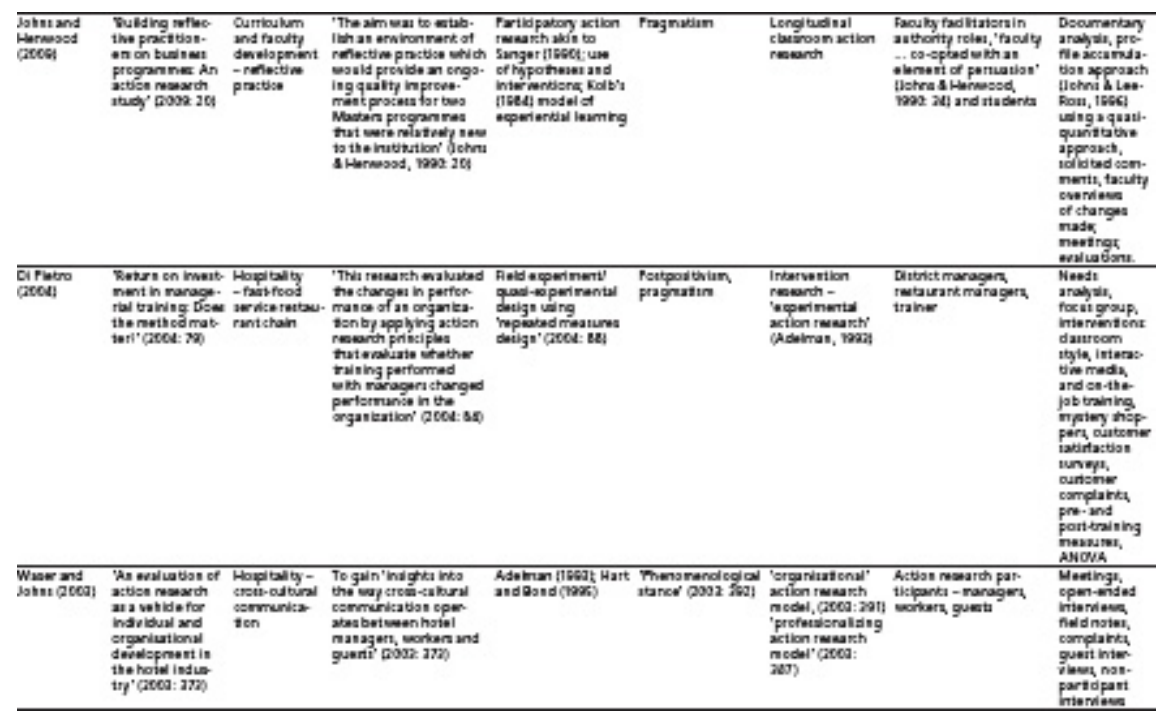

(2) Were there 'reflexive-practical outcome[s]' (Bradbury \& Reason, 2006: 347)? Essentially, is the inquiry 'validated', do participants comment 'that was useful - I am using what I learned!' (Bradbury \& Reason, 2006: 347)?

(3) Is there a focus on the 'plurality of knowing' (Bradbury \& Reason, 2006: 347)? Is there 'conceptual-theoretical integrity' - is theory practical? Does theory positively re-vision the research setting and context? And does it debunk accepted or dated theories that 'other' peoples? Are various ways of knowing explored and utilised? Is theory shared in creative ways beyond 'written accounts'?

(4) Is the inquiry significant? And why - what values are held by those involved and with regard to the inquiry itself? What makes the inquiry significant?

(5) Are there 'enduring consequences' of the inquiry? Does first-, second- and/or third-person action research embrace and harness different ways of knowing/understanding/theorising the world? Does theory/practice create new actions and change orthodox patterns of acting and behaving?

Case study: Action research in practice

This case study represents third-person action research. As this chapter focuses on action research as a process of inquiry, the case study will discuss the process methods used rather than 'report' the case study as would occur in a journal article.

In 2008, Jennings et al. participated in a national research programme initiated and financially supported by the Australian government's Department of the Environment, Water, Heritage and the Arts (DEWHA). The Australian Research Institute in Education for Sustainability (ARIES) with the support of Macquarie University, Australia, facilitated the programme. The aim of the programme was 'to create change for sustainability in the learning and teaching focus of the five participating Australian business schools and in the operations of the business schools and their partner corporations' (Thomas \& Benn, 2009: 8). The underlying tenet of the programme was the use of action research specifically focused on 'Education about and for Sustainability in Australian Business Schools Stage 3' (Thomas \& Benn, 2009: 8). Jennings et al. (2008) represented one of the five business school teams involved in the programme.

The action research-based programme utilised 'a multiple-case-study approach (Yin, 2003)' (Thomas \& Benn, 2009: 19), and emphasised a 'learning-based approach to embedding systemic change' (Thomas \& Benn, 2009: 19). 'Core to the ARIES model for learning-based change [were]:

- envisioning alternative futures

- participation and partnership

- critically reflective thinking

- systemic practice

- iterative learning through social interactions' (Thomas \& Benn, 2009: 20).

As the action research was third-person action research, it involved a range of participants. At the programme level, there was a programme leader and coordinator and a programme advisor. At the business school level, there was a project research leader/co-researcher with co-researcher teaching staff and, variously in some business schools, a mentor, research assistant and a supporter. Additionally, co-researchers and/or co-learners were students and industry partners. In several institutions, multiple action research projects were conducted under the overarching institutional action research project.

During the action research processes, the programme leader and programme coordinator as co-researchers continuously connected using voice-to-voice technologies with each of the business school co-researchers as a collective and facilitated reflection on the action research being undertaken at each institution. Email contact was also used as a means of communication. The programme leader and coordinator facilitated face-to-face interactions between representatives from 
each of the business school participants at a central location. During these interactions, as well as reflection, learning opportunities were presented, which had arisen out of the programme leader and coordinators conversations with all programme action research participants. These interactions were then shared with the representative's co-researchers at the institutional level. Vocabulary used in the programme included change agents, champions, communities of practice, co-researchers and co-learners.

At the outset, ARIES identified the action research cycle for the programme. To address the previously mentioned nature of overlap or multiple processes inputting into action cycles, Figure 5.2 provides a different representation from Figure 5.1 in order to capture this fluidity.

Each institution utilised different projects and different methods. For details, refer to Thomas and Benn (2009).

The institutional project, which is the focus of this case study, had the following aims:

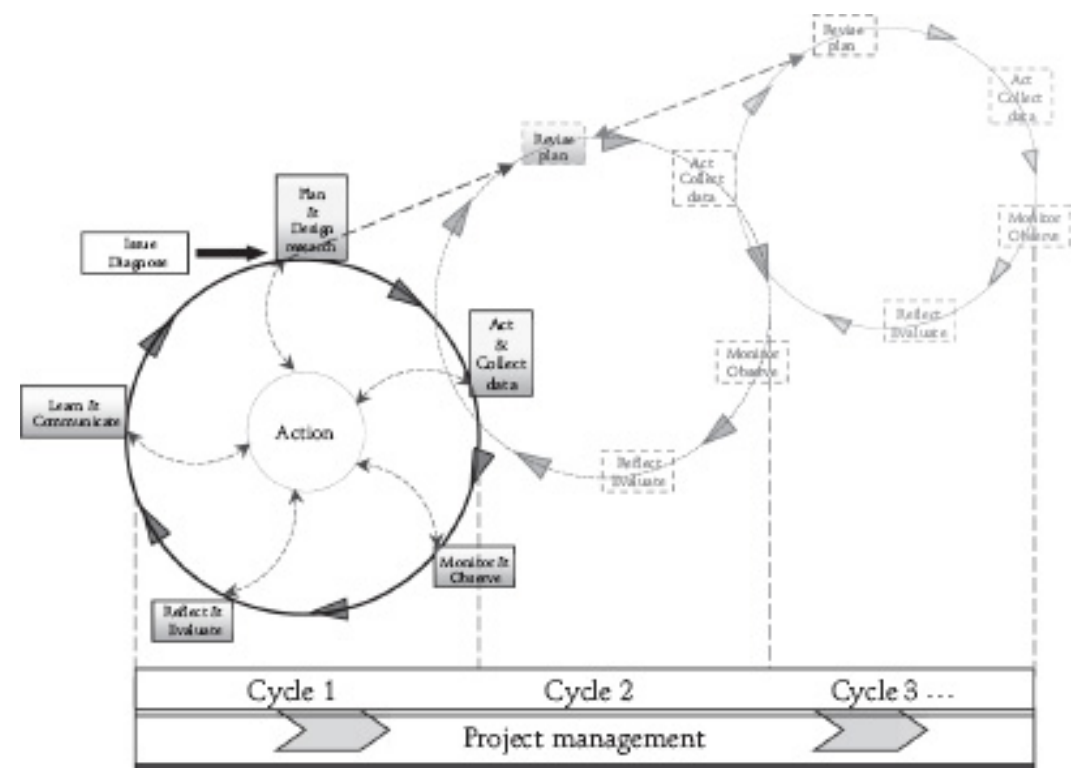

Figure 5.2 ARIES action research cycles (Source: Thomas \& Benn, 2009: 20)

- to partner with micro, small and medium tourism enterprises ... in order to engender and/or further enhance sustainability principles associated with such enterprises' tourism operations;

- to improve pedagogy, andragogy, ethnogogy, as well as curriculum content of four courses ... in addition to enhancing educational praxis associated with Education about Sustainability/for Sustainability within the [Business School] (Jennings et al., 2008: iv)

The institutional project was an umbrella project under which four separate action research inquiries undertaken in a postgraduate course and three undergraduate courses were housed. The institutional action research inquiry occurred in concert with the four course-related action research inquiries. The institutional inquiry was akin to second-person research/practice and the individual course-based action research inquiries to first-person research/practice.

The institutional action research team comprised four academic staff members, a project assistant, students enrolled in the three courses and 10 micro, small, medium tourism enterprise (MSME) partners.

The institutional and course-related action research inquiries were founded on PAR and were paradigmatically informed by a critical theory orientation. The following methods served to "capture the "project-in-action": lived experience, reflexive team conversations, team journals, reflexive journals, interviews, focus groups, and student learning materials' (Jennings et al., 2008: 11). Both formative and summative evaluation methods were used.

Formative evaluation methods included 'reflexive journals by students and course convenors', 'reflexive conversations between project team members' as well as 'industry participants' and 'other business school participants', 'dialogue with ARIES team members' as well as 'other business school participants', semi-structured 'interviews with students and industry', as well as 'monitoring shifts in understanding' with regard to education about sustainability and education for sustainability (Jennings et al., 2008: 14).

Summative evaluation methods included 'reflexive focus groups involving project team members', and 'students from each of the courses', 'reflexive interviews with students from courses', student evaluation via learning/teaching questionnaires, content analysis and/or successive approximation of empirical materials, 'comparisons of pre- and post-empirical materials' as well as 'pre- and post-reflections' regarding 'knowledge, skills and practices associated with sustainability for students, academics and business partners', reviews by industry during a workshop and dissemination processes of project materials, along with ARIES and DEWHA, and peer review of documentation related to disseminating 'outcomes' of the institutional action research inquiry - education about and for sustainability (Jennings et al., 2008: 14). 
Student-based empirical materials were interpreted using content analysis, while successive approximation was used to interpret industry-based empirical materials (Jennings et al., 2008). For further details refer to Jennings et al. (2008).

While this example has been drawn from a co-partnered university-government initiative, it provides an example of instigating change in practices associated with training and education. There is immediate transferability of the action research processes to human resource development, casual employee training, full-time staff training, volunteer training and the transfer of the processes to other organisations such as tourism associations, conference and convention associations and large networked tourism organisations. The case study indicates ways to connect with others to undertake a third-person action research process, which had embedded within it both second- and first-person action research aspects. Other examples of the use of action research in tourism and hospitality were provided in the 'Research Contexts' section. Additional examples are provided in Table 5.3.

\section{Conclusion}

As already noted, action research has been used throughout history as a means to solve issues. In the first half of the 20th century, several people were associated with 'formally' developing action research, specifically Lewin and Collier. The main difference between action research and other research approaches is that action research unites theory and practice, that is, theory/practice. It emphasises knowing-in-action. Other research approaches tend to separate theory and practice by generating theory first and then considering the implications for practice. Although action research has been critiqued for its emphasis on practice, it has become an accepted way of conducting research. Today, it is a global research approach. Its foundations stem from Lewin's (1946) articulation of cyclic processes of 'planning, 'action' and 'fact finding' in order to improve the worlds of people and their circumstances.

Paradigmatically, in its objectively determined experimental and mixed methods forms, action research aligns with postpositivism. Action research, which is not fully participatory and based on equality with regard to research design and decision-making, aligns with social constructivism and critical theories paradigms. In 1997, Heron and Reason argued for a participatory paradigm, which advocated that those affected need to be collaboratively engaged in all aspects of action research inquiries as equal members, and that democratic dialogue, critical subjectivity and critical intersubjectivity should guide actions and decisions.

Arising from the four paradigmatic perspectives, a range of action research approaches has developed, such as experimental, empirical, participant and diagnostic. Within social constructivism, critical theories and participatory paradigms, a family of approaches has developed, such as action research, participatory (action) research, appreciative inquiry, action science, community action research and action learning. In addition, action research has been classified as first-, second- and third-person research/practice.

Action research involves successive cycles of identifying an issue, making a plan, acting and observing the plan, reflecting on the plan, altering the plan and so on. Within tourism and hospitality studies, action research has been used, for example, with respect to community participation in tourism planning, product and experience development, service innovation, organisational and professional development and practice, organisational change, engendering learning and as a means to enhance training and education.

Given the diversity of approaches to action research, it behooves those interested in its use to read widely and familiarise themselves with the paradigmatic perspectives, and related action research approaches. In doing so, the best approach for redressing an issue and for the people affected can be determined in order to cyclically link theory and practice and simultaneously improve people's circumstances.

How do we judge quality in action research? Five criteria were suggested related to 'relational praxis', 'reflexive-practical outcomes', 'plurality of knowing', significance and 'enduring consequences' (Bradbury \& Reason, 2006: 346-349). And finally, we need to remember as Reason and Bradbury (2006a) noted:

...the primary purpose of action research is not to produce theories based on action; nor is it to produce theories about action; nor is it to produce theoretical or empirical knowledge that can be applied in action; it is to liberate the human body, mind and spirit in the search for a better, freer world. (Reason \& Bradbury, 2006a: 2)

\section{References}

Adelman, C. (1993) Kurt Lewin and the origins of action research. Educational Action Research 1 (1), 7-24.

Afify, M.F. (2008) Action research: Solving real-world problems. Tourism and Hospitality Research 8, $153-159$.

Argyris, C. and Schön, D. (1974) Theory in Practice: Increasing Professional Effectiveness. San Francisco, CA: Jossey-Bass. Argyris, C. and Schön, D. (1978) Organizational Learning. Reading MA: Addison-Wesley.

Argyris, C., Putnam, R. and Smith, D. (1985) Action Science: Concepts, Methods, and Skills for Research and Intervention. San Francisco, CA: Jossey-Bass.

Bateson, G. (1972) The logical categories of learning and communication. In G. Bateson (ed.) Steps to an Ecology of Mind (pp. 250-279). San Francisco, CA: Chandler.

Björk, P. (2014) The DNA of tourism service innovation: A quadruple helix approach. Journal of Knowledge Economy 5, $181-202$.

Bradbury, H. (1998) Learning with the Natural Step: Cooperative Ecological Inquiry Through Cases Theory, and Practice for Sustainable Development. Chestnut Hill, MA: Boston College Organizational Studies Doctoral Dissertation. 
Bradbury, H. and Reason, P. (2006) Conclusion: Broadening the bandwith of validity: Issues and choice-points for improving the quality of action research. In P. Reason and H. Bradbury (eds) Handbook of Action Research, Concise Paperback Version (pp. 343-351). London: Sage Publications.

Brydon-Miller, M., Maguire, P. and McIntyre, A. (2004) Traveling Companions: Feminism, Teaching, and Action Research. Westport, CT: Greenwood Publishing Group.

Burns, R.B. (2000) Introduction to Research Methods (4th edn). London: Sage Publications.

Bushe, G.R. (2007) Why appreciative inquiry is unlikely to generate research publications. AI Practitioner (Special Issue: Using Appreciative Inquiry for Research) 3, 2-11.

Carr, W. and Kemmis, S. (1986) Becoming Critical: Education, Knowledge and Action Research. Basingstoke: Falmer.

Cole, S. (2006) Information and empowerment: The keys to achieving sustainable tourism. Journal of Sustainable Tourism 14 (6), 629-644.

Cooperrider, D.L. (1986) Appreciative inquiry: Toward a methodology for understanding and enhancing organizational innovation. Unpublished doctoral dissertation, Case Western Reserve University.

Cooperrider, D.L. (1998) Capturing What Matters Most in the Practice of Appreciative Inquiry: A Positive Revolution in Change. Paper presented at the Academy of Management Annual Meeting, San Diego, CA.

Cooperrider, D.L. and Srivastva, S. (1987) Appreciative inquiry in organizational life. In R. Woodman and W. Pasmore (eds) Research on Organizational Change and Development (pp. 129-169). Greenwich, CT: JAI Press.

Dewey, J. (1938) Experience and Education. New York: Collier Books.

Dick, B. (2004) Action research literature. Action Research 4, 425-444.

Dick, B. (2006) Action research literature 2004-2006: Themes and trends. Action Research 4, 439-458.

DiPietro, R.B. (2004) Return on investment in management training: Does the method matter? Journal of Foodservice Business Research 7 (4), 79-96.

Fals Borda, O. (2006) Participatory (Action) research in social theory: Origins and challenges. In P. Reason and H. Bradbury (eds) Handbook of Action Research, Concise Paperback Version (pp. 27-37). London: Sage Publications.

Fals-Borda, O. and Rahman, M.A. (1991) Action and Knowledge: Breaking the Monopoly with Participatory Action Research. New York: Intermediate Technology/Apex.

Flood, R.L. (2006) The relationship of 'systems thinking' to action research. In P. Reason and H. Bradbury (eds) Handbook of Action Research, Concise Paperback Version (pp. 117-128). London: Sage Publications.

Freire, P. (1970) Pedagogy of the Oppressed. New York: Herder \& Herder.

French, W. and Bell, C. (1984) Organization Development: Behavioral Science Interventions for Organizational Improvement. Engelwood Cliffs, NJ: Prentice-Hall.

Friedman, V.J. (2006) The practice of co-operative inquiry: Research 'with' rather than 'on' people. In P. Reason and H. Bradbury (eds) Handbook of Action Research, Concise Paperback Version (pp. 131-143). London: Sage Publications.

Garcia-Rosell, J-C. and Makinen, J. (2013) An integrative framework for sustainability evaluation in tourism: Applying the framework to tourism product development in Finnish Lapland. Journal of Sustainable Tourism 21 (3), 396-416.

Grant, S. and Humphries, M. (2006) Critical evaluation of appreciative inquiry: Bridging an apparent paradox. Action Research 4, 401-418.

Guba, E.G. (1990) The alternative paradigm dialog. In E.G. Guba (ed.) The Paradigm Dialog (pp. 17-27). Newbury Park, CA: Sage Publications. Guba, E.G. and Lincoln, Y.S. (1989) Fourth Generation Evaluation. Newbury Park, CA: Sage Publications.

Guba, E.G. and Lincoln, Y.S. (1994) Competing paradigms in qualitative research. In N.K. Denzin and Y.S. Lincoln (eds) The Sage Handbook of Qualitative Research (1st edn; pp. 105-117). Thousand Oaks, CA: Sage Publications.

Guba, E.G. and Lincoln, Y.S. (2005) Paradigmatic controversies, contradictions, and emerging confluences. In N.K. Denzin and Y.S. Lincoln (eds) The Sage Handbook of Qualitative Research (3rd edn; pp. 191-215). Thousand Oaks, CA: Sage Publications.

Gustavsen, B. (1996) Development in the social sciences: An uneasy relationship. In S. Toulmin and B. Gustavsen (eds) Beyond Theory: Changing Organizations through Participation (pp. 5-30). Amsterdam: John Benjamins.

Gustavsen, B. (2006) Theory and practice: The mediating discourse. In P. Reason and H. Bradbury (eds) Handbook of Action Research, Concise Paperback Version (pp. 17-26). London: Sage Publications.

Gustavsen, B. and Engelstad, P.H. (1986) The design of conferences and the evolving role of democratic dialogue in changing working life. Human Relations 39 (2), 101-116.

Habermas, J. (1974) Theory and Practice (J. Viertel, trans.). London: Heinemann.

Hall, B.L. (2001) I wish this were a poem of practices of participatory research. In P. Reason and H. Bradbury (eds) Handbook of Action Research: Participative Inquiry and Practice (pp. 171-178). London: Sage Publications.

Hammond, S. (1996) The Thin Book of Appreciative Inquiry. Plano, TX: Thin Book Publishing Company.

Hart, E. and Bond, M. (1995) Action Research for Health and Social Care: A Guide to Practice. Milton Keynes: Open University Press.

Heron, J. (1971) Experience and Method: An Inquiry into the Concept of Experiential Research. Guildford: University of Surrey, Human Potential Research Project.

Heron, J. (1996) Cooperative Inquiry. London: Sage Publications.

Heron, J. and Reason, P. (1997) A participatory inquiry paradigm. Qualitative Inquiry 3 (3), 274-294.

Heron, J. and Reason, P. (2006) The practice of co-operative inquiry: Research 'with' rather than 'on' people. In P. Reason and H. Bradbury (eds) Handbook of Action Research, Concise Paperback Version (pp. 144-154). London: Sage Publications.

Idziak, W., Majewski, J. and Zmyslony, P. (2015) Community participation in sustainable rural tourism experience creation: A long-term appraisal and lessons from a thematic villages project in Poland. Journal of Sustainable Tourism 23 (8-9), 1341-1362.

Jennings, G. (2010) Tourism Research (2nd edn). Brisbane: John Wiley.

Jennings, G., Cater, C., Hales, R., Hornby, G. and Kensbock, S. (2008) Engendering and Enhancing Sustainability Principles and Practices for Small Tourism Business Enterprises. Report, Circulation: Australian Research Institute in Education for Sustainability, Australian Government Department for the Environment, Water, Heritage and the Arts. See http://aries.mq.edu.au/projects/MBA3/GBS_Report.pdf (accessed on 5 September 2017).

Jennings, G., Scantlebury, M., and Wolfe, K. (2009) Tertiary travel and tourism education: Using action research cycles to provide information on pedagogical applications associated with reflexivity, team-based learning and communities of practice. Journal of Teaching in Travel and 
Tourism 9 (3\&4), 193-215.

Jennings, G.R. and Seiler, V.L. (2000) Organizational change in the tourism industry: If there's a problem - Then change your point of view. In C.H.C. Hsu (ed.) The International Society of Travel and Tourism Educators Annual Conference Proceedings, Tampa, Florida, October 5-7, Reunion 2000: Our Past, Our Future (pp. 72-76) ISTTE: Harper Woods, MI, USA.

Johns, N. and Lee-Ross, D. (1996) Profile accumulation: A quality assessment technique for hospitality SMEs. In R. Teare and C. Armistead (eds) Services Management: New Directions and Perspectives (pp. 101-104). London: Cassell.

Johns, N. and Henwood, J. (2009) Building reflective practitioners on business programmes: An action research study. Journal of Hospitality, Leisure, Sport and Tourism Education 8 (1), 20-36.

Kelliher, F., Foley, A. and Frampton, A-M. (2009) Facilitating small firm learning networks in the Irish tourism sector. Tourism and Hospitality Research 9 (1), 80-95.

Kemmis, S. (2006) Exploring the relevance of critical theory for action research: Emancipatory action research in the footsteps of Jürgen Habermas. In P. Reason and H. Bradbury (eds) Handbook of Action Research, Concise Paperback Version (pp. 94-105). London: Sage Publications.

Kemmis, S. and McTaggart, R. (1988) Introduction: The nature of action research. In S. Kemmis and R. McTaggart (eds) The Action Research Planner (pp. 5-28). Burwood, VIC: Deakin University Press.

Kemmis, S. and McTaggart, R. (2005) Participatory action research: Communicative action and the public sphere. In N.K. Denzin and Y.S. Lincoln (eds) The Sage Handbook of Qualitative Research (3rd edn; pp. 559-603) Thousand Oaks, CA: Sage Publications.

Kolb, D.A. (1984) Experiential Learning Experience as a Source of Learning and Development. Englewood Cliffs, NJ: Prentice Hall.

Koster, R.L.P. and Lemelin, R.H. (2009) Appreciative inquiry and rural tourism: A case study from Canada. Tourism Geographies 11 (2), 256-269.

Lashley, C. (2000) Action research: An essential tool for hospitality management education? Tourism and Hospitality Research 1 (4), $313-327$.

Lewin, K. (1939) Field theory and experiment in social psychology: Concepts and methods. American Journal of Sociology 44 (6), 868-896.

Lewin, K. (1946) Action research and minority problems. Journal of Social Issues 2 (4), 34-46.

Lincoln, Y.S. and Guba, E.G. (2000) Paradigmatic controversies, contradictions, and emerging confluences. In N.K. Denzin and Y.S. Lincoln (eds) The Sage Handbook of Qualitative Research (2nd edn; pp. 163-188). Thousand Oaks, CA: Sage Publications.

Lincoln, Y.S., Lynham, S.A and Guba, E.G. (2011) Paradigmatic controversies, contradictions, and emerging confluences, revisited. In N.K. Denzin and Y.S. Lincoln (eds) The Sage Handbook of Qualitative Research (4th edn; pp. 97-128). Thousand Oaks, CA: Sage Publications.

Ludema, J.D., Cooperrider, D.L. and Barrett, F.J. (2006) Appreciative inquiry: The power of the unconditional positive question. In P. Reason and H. Bradbury (eds) Handbook of Action Research, Concise Paperback Version (pp. 155-165). London: Sage Publications.

Lyon, J. (1998/1999) Applying Hart and Bond's typology: Implementing clinical supervision in an acute setting. Nurse Researcher 6 (2), $39-56$.

Maguire, P. (2006) Uneven ground: Feminisms and action research. In P. Reason and H. Bradbury (eds) Handbook of Action Research, Concise Paperback Version (pp. 60-70). London: Sage Publications.

Marrow, A.J. (1969) The Practical Theorist: The Life and Work of Kurt Lewin. New York: Basic Books.

Marshall, J. and Reason, P. (1994) Adult learning in collaborative action research: Reflections on the supervision process. Studies in Continuing Education: Research and Scholarship in Adult Education 15 (2), 117-132.

Marsick, V.J. and O'Neil, J. (1999) The many faces of action learning. Management Learning 30 (2), 159-176.

McGill, I. and Beaty, L. (1992) Action Learning: A Practitioner's Guide. London: Kogan Page.

Mies, M. (1993) Feminist research: Science, violence and responsibility. In M. Mies and V. Shiva (eds) Ecofeminism (pp. 36-54). London: Zed Books.

Mitchell, J. (2012) Value chain approaches to assessing the impact of tourism on low-income households in developing countries. Journal of Sustainable Tourism 20 (3), 457-475.

Morawski, J. (2001) Feminist research methods: Bringing culture to science. In D. Tolman and M. Brydon-Miller (eds) From Subjects to Subjectivities: A Handbook of Interpretive and Participatory Methods (pp. 57-75). New York: New York University Press.

Olesen, V. (1994) Feminisms and models of qualitative research. In N.K. Denzin and Y.S. Lincoln (eds) Handbook of Qualitative Research (1st edn; pp. 158-174). Thousand Oaks, CA: Sage Publications.

Pålshaugen, Ø. (2014) Action research for democracy: A Scandinavian approach. International Journal of Action Research 10 (1), $98-115$.

Pasmore, W. (2006) Action research in the workplace: The socio-technical perspective. In P. Reason and H. Bradbury (eds) Handbook of Action Research, Concise Paperback Version (pp. 38-48). London: Sage Publications.

Paül, V., Trillo-Santamaría, J-M. and Pérez-Costas, P. (2015) Action research for tourism planning in rural areas? Examining an experience from the Couto Mixto (Galicia, Spain). Geographical Research 54 (2), 153-164.

Pedler, M. (1991) Preface. In M. Pedler (ed.) Action Learning in Practice (2nd edn). Brookfield, VT: Gower.

Putnam, R.W. (1999) Transforming social practice: An action science perspective. Management Learning 30 (2), $177-187$.

Rapoport, R.N. (1970) Three dilemmas of action research. Human Relations 23, 499-513.

Reason, P. (2004) Action research and the single case: A response to Bjørn Gustavsen. Concepts and Transformations 8 (3), $281-294$.

Reason, P. (1994) Three approaches to participative inquiry. In N.K. Denzin and Y.S. Lincoln (eds) The Sage Handbook of Qualitative Research (1st edn; pp. 324-339). Thousand Oaks, CA: Sage Publications.

Reason, P. (1995) Participation in Human Inquiry. London: Sage Publications.

Reason, P. and Torbert, W.R. (2001) The action turn: Towards a transformational social science. Concepts and Transformations 6 (1), 1-37.

Reason, P. and Bradbury, H. (2006a) Introduction: Inquiry and participation in search of a world worthy of human aspiration. In P. Reason and H. Bradbury (eds) Handbook of Action Research, Concise Paperback Version (pp. 1-14). London: Sage Publications.

Reason, P. and Bradbury, H. (2006b) Preface. In P. Reason and H. Bradbury (eds) Handbook of Action Research, Concise Paperback Version (pp. xxi-xxxii). London: Sage Publications.

Reason, P. and Bradbury, H. (eds) (2006c) Handbook of Action Research, Concise Paperback Version. London: Sage Publications.

Revans, R.W. (1982) The Origins and Growth of Action Learning. Lund: Studentlitteratur.

Sanger, J. (1990) Awakening a scream of consciousness: The critical group in action research. Theory into Practice 29 (3), $174-178$.

Schmitz, S. and Tsobgou, D.L. (2016) Developing tourism products and new partnerships through participatory action research in rural Cameroon. Geographical Research 54 (2), 143-152. 
Schön, D.A. (1983) The Reflective Practitioner: How Professionals Think in Action. New York: Basic Books.

Senge, P.M. and Scharmer, C.O. (2006) Community action research: Learning as a community of practitioners, consultants and researchers. In P. Reason and H. Bradbury (eds) Handbook of Action Research, Concise Paperback Version (pp. 195-206). London: Sage Publications.

Stufflebeam, D.L. (2008) Egon Guba's conceptual journey to constructivist evaluation: A tribute. Qualitative Inquiry 14 (8), $1386-1400$.

Susman, G. and Evered, R. (1978) An assessment of the scientific merits of action research. Administrative Science Quarterly 23, 582-603.

Swantz, M-L., Ndedya, E. and Masaiganah, M.S. (2006) Participatory action research in southern Tanzania, with special reference to women. In P. Reason and H. Bradbury (eds) Handbook of Action Research, Concise Paperback Version (pp. 286-303). London: Sage Publications.

Thomas, J. and Benn, S. (2009) Education about and for Sustainability in Australian Business Schools Stage 3. A report prepared by the Australian Research Institute in Education for Sustainability for the Australian Government Department of the Environment, Water, Heritage and the Arts. See http://aries.mq.edu.au/projects/MBA3/AustBusinessSchools3.pdf (accessed 15 September 2016).

Torbert, W.R. (1991) The Power of Balance: Transforming Self, Society, and Scientific Inquiry. Newbury Park, CA: Sage Publications.

Torbert, W. (1998) Developing courage and wisdom in organizing and sciencing. In S. Srivastva and D. Cooperrider (eds) Organizational Wisdom and Executive Courage (pp. 222-253). San Francisco: The New Lexington Press.

Torbert, W.R. (1999a) The distinctive questions developmental action inquiry asks. Management Learning 30 (2 June), $189-206$.

Torbert, W. (1999b) Transforming social science: Integrating quantitative, qualitative, and action research. In F. Sherman and W. Torbert (eds) Transforming Social Inquiry, Transforming Social Action: Creating Communities of Practice at the University and in the Community (pp. 67-91). Norwood MA: Kluwer Academic Publishers.

Torbert, W. (1999c) The call to bridge knowledge and action: The response of the Boston College PhD Program in organization transformation. In F. Sherman and W. Torbert (eds) Transforming Social Inquiry, Transforming Social Action: Creating Communities of Practice at the University and in the Community (pp. 247-273). Norwood MA: Kluwer Academic Publishers.

Torbert, W.R. (2006) The practice of action inquiry. In P. Reason and H. Bradbury (eds) Handbook of Action Research, Concise Paperback Version (pp. 207-217). London: Sage Publications.

Wallerstein, N.B. and Duran, B. (2006) Using community-based participatory research to address health disparities. Health Promotion Practice 7 , 312-313.

Waser, H. and Johns, N. (2003) An evaluation of action research as a vehicle for individual and organisational development in the hotel industry. International Journal of Hospitality Management 22 (4), 373-393.

Whitney-Squire, K. (2016) Sustaining local language relationships through indigenous community-based tourism initiatives. Journal of Sustainable Tourism 24 (8-9), 1156-1176.

Whyte, W.F. (1989) Advancing scientific knowledge through participatory action research. Sociological Forum 4 (3), 3-38.

Whyte, W.F. (1991) Introduction. In W.F. Whyte (ed.) Participatory Action Research (pp. 7-15). Sage Focus Edition. Newbury Park, CA: Sage Publications.

Zuber-Skerritt, O. (1996) Introduction: New directions in action research. In O. Zuber-Skerritt (ed.) New Directions in Action Research (pp. 3-10). London: Routledge. 


\title{
6 Participant Observation in Cross-Cultural Tourism Research
}

\author{
Kylie Radel
}

Collecting data in the field through observation of, and participation in, the daily lived experiences of the research site is a fundamental technique for qualitative tourism researchers who wish to study communities and their interactions within their unique social and cultural contexts. However, while conducting qualitative tourism research in the field is a long-accepted practice, the practices and processes of observation and participant-observation may represent intrusive, fundamentally contentious processes for the variety of cultures and communities who are often viewed as subjects, as well as for researchers themselves.

For example, research conducted with Indigenous populations worldwide has been challenged through issues of controversial mismanagement and perceived endemic disrespect (Caldwell et al., 2005; Cochran et al., 2008; Dodson, 2000; Rigney, 1999; Smith, 1999). As indicated by Martin (2003: 203), research in Australia 'on Aboriginal people ... [and] on Aboriginal lands was done without the permission, consultation, or involvement of Aboriginal people'. Indigenous communities globally tend to regard research as a form of 'exploitation' (Dodson, 2000: 56) and researchers with 'scepticism' (Cochran et al., 2008: 22) and often intense distrust (Arbour \& Cook, 2006; Episkenew \& Wheeler, 2002). Similar perspectives are held by many other communities and individuals who come under researchers' scrutiny.

Qualitative researchers seek to understand situations and contexts, interpret actions and develop deep knowledge of interactions and relationships. However, at times the investigative process that aims to give voice to participants has the extraordinary capacity to marginalise and exclude those who are subsequently othered (Hall, 1997) through the research subjectivities; and particularly those in positions of fragility. Qualitative tourism researchers may need to confront their own personal standpoints and their situatedness in the field contexts; evaluate and recognise their relationships with participants; interpret cultural contexts; and scrutinise their capacity to appropriately represent and interpret the voices and stories. The processes, practices and outcomes from field research and participant-observation in tourism need to be conscious of, and applicable for, culturally diverse and potentially ethically divergent communities.

This chapter examines the practices and processes of participant-observation within qualitative tourism research and proposes a new model of research partnering for effective field research. The study on which this chapter is based employed a constructivist, qualitative, grounded theory approach and identified the key success factors for an Indigenous tourism enterprise in the Australian tourism industry. As a non-Indigenous researcher working in an Indigenous research context, I was deeply conscious that the research explicitly demonstrated the principles and protocols of Indigenous research methodologies (Radel, 2010). Throughout the research (used as the case study for this chapter), I sought to foreground the voices and perspectives of Indigenous community members rather than interpret the data through Westernised business research lenses. This chapter focuses on one of the significant findings from the study that challenges previous assumptions around the practices, processes and fundamental positionalities of participant-observation and naturalistic inquiry specifically when applied in the contexts of a cross-cultural tourism research design. This chapter first provides an overview of the historical perspectives of observation, participant-observation and naturalistic inquiry. The model of reflexive research partnering is then defined and explained. It is proposed as an alternative approach to traditional models of participant-observation that is cognisant of the researcher's positionality, situatedness and data collection techniques as well as being appropriate for the community in (and for) which the research is conducted. While the model is underpinned by Indigenous tourism research contexts, the research partnering model is offered as an approach relevant to any qualitative researcher conducting fieldwork within cross-cultural tourism sites.

\section{Observation, Participant-Observation and Naturalistic Inquiry}

The processes of conducting research in the field through observation, participant-observation and naturalistic inquiry within tourism and social sciences have undergone significant development and refinement over time (Baker, 2008). Observation is a complex method of data collection that is generally appropriate for studies that seek to describe the interactions and behaviours of a group 'who interact with each other on a regular basis in a relatively fixed setting' (Neuman, 2000: 345).

However, observation and fieldwork's origins in early European history enabled the practices of these anthropological studies to develop in ways that did not 'honour the status' (Nakata, 1998: 7) of Indigenous peoples and Indigenous research contexts. Early explorers and missionaries were encouraged to investigate distant cultures (Neuman, 2000; Tedlock, 2000), write extensively on the lifestyles and activities of peoples they encountered, take measurements, examine and seize tools and cultural artefacts and misappropriate culture (see, for example, Cushing, 1979). Such investigations were conducted from 